This item was submitted to Loughborough's Research Repository by the author.

Items in Figshare are protected by copyright, with all rights reserved, unless otherwise indicated.

\title{
Book Review: Promotional cultures: The rise and spread of advertising, public relations, marketing and branding
}

PLEASE CITE THE PUBLISHED VERSION

http://dx.doi.org/10.1177/1940161215626948

\section{PUBLISHER}

(C) The Authors. Published by Sage.

\section{VERSION}

AM (Accepted Manuscript)

\section{PUBLISHER STATEMENT}

This work is made available according to the conditions of the Creative Commons Attribution-NonCommercialNoDerivatives 4.0 International (CC BY-NC-ND 4.0) licence. Full details of this licence are available at: https://creativecommons.org/licenses/by-nc-nd/4.0/

\section{LICENCE}

CC BY-NC-ND 4.0

\section{REPOSITORY RECORD}

Wring, Dominic. 2019. "Book Review: Promotional Cultures: The Rise and Spread of Advertising, Public Relations, Marketing and Branding”. figshare. https://hdl.handle.net/2134/21263. 
Aeron Davis, Promotional Cultures: the Rise and Spread of Advertising, Public Relations, Marketing and Branding. Polity 2013

This is an impressive book on various levels. Firstly it is a highly accessible account that will engage general readers as well as more knowledgeable subject specialists. Further to this Promotional Cultures covers a wide range of topics and debates in ways that introduce and relate the points before going on to provide greater analytical and empirical depth without becoming mired in too much detail. This is no mean feat given the proliferation of obscure jargon, flowery language and colourful metaphors that characterize some of the burgeoning writings on both marketing promotion and culture over the last three decades. Page after page of this book is full of useful information and is testimony to the careful and considered way this account has been put together. Aeron Davis' considered synthesizing of this literature also takes careful account of contributions from management as well as media and cultural studies' perspectives not to mention those in both fields who might be characterized as mainstream or critical observers. The latter have been particular to the fore in recent years given a renaissance in the questioning of the prevailing neo-liberal political economy orthodoxy and the New Right ascendancy behind it. The catalyst for much of this re-evaluation is a 2008 crisis that provides a timely backdrop and frames Davis's thoughtfully conceived and well executed book. Fittingly it also includes a chapter on the money markets written by an author who can distinguish fact from fiction having earlier completed a study that had brought him into contact with many of those working in high end PR at the dawn of the millennium. Several of these worked on behalf of elite financiers, the very people who precipitated the subsequent crash.

If nothing else the catastrophic events of 2008 should have marked a downturn in the fortunes of Tony Robbins, Oprah Winfrey and other proselytizers of the cult of individualism, you can be anything you want to be philosophy of 'personal branding' that had long prevailed. This phenomenon grew in the slipstream of the New Right's forging of a free market consensus that begat the 'New' Democrat and Labour eras whose celebration of dynamism and change was much vacuous rhetoric. Clinton and Blair presided over economies that endorsed the trajectories established by Reagan and Thatcher, their immediate predecessors but one. Central to this was the development of a service sector and within this an unprecedented burgeoning of the advertising, PR and market research industries. It was appraisal of these developments that informed Andrew Wernick's 1991 Promotional Culture, the title and theme which inspires this book. As Davis explains the earlier contribution was important for asserting that "there is 'an alteration in the very relations between culture and economy', characterized by the hegemony of 'pan-promotionalism' over the 'economic base'" (p.67). Wernick examined this by exploring how higher education, politics and even commercial discourses themselves were being transformed by rapacious ideological force. 
Wernick's account remains influential but was in need of revisiting and updating which is what in part Davis's work amply provides, among many other things, with a tour of theoretical works as well as insightful case studies looking at various subjects including celebrity and politics of both the formal and informal varieties. This in the context of a crisis of capitalism that has, among some public intellectuals at least, led to concerted re-examination of social, political and economic consequences of the marketization of society, state and economy during the 1980s and its condoning during the decade that followed. Aeron Davis' book then follows in the tradition of other critical assessments, notably those by cultural critics such as Tom Frank and Naomi Klein. But what is telling about Davis' account is that, despite exploring concerns about the relationship between rising promotional activity and the fostering of inequality, this is interspersed with pithy summaries of the advertisers and PR consultants' own rationales for their social and economic significance. Here Davis approvingly quotes Don Slater's observation: 'Marketing is not only about competition within markets, within given structures. It is a competition over the structures of markets and market relations themselves. Every firm wants to redefine the boundaries of markets by reframing goods' (p.82). This focus re-emphasizes the importance of considering how marketers are cultural and media producers who shape and reshape the environment quite apart from the market specific promotional activities in which they engage. Davis thereby revisits the earlier work of Ewen among others who have forensically documented the rise of a consumerist ideology only to be dismissed as characterizing the public as gullible dupes. What Promotional Cultures captures so well is how marketing 'effects' should not be so narrowly construed and rather be more concerned with systemic rather than narrower definitions of impact and influence. Much contemporary promotional cultural activity is, after all, more concerned with protecting existing interests rather than necessarily expanding business in markets that are best characterized as oligopolies or even virtual monopolies. 